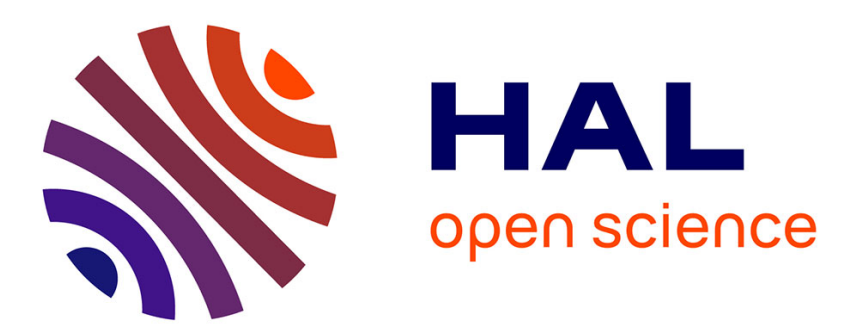

\title{
Ciprofloxacin stress proteome of the extended-spectrum beta-lactamase producing Escherichia coli from slaughtered pigs
}

Sónia Ramos, Ingrid Chafsey, Michel Hébraud, Margarida Sousa, Patrícia Poeta, Gilberto Igrejas

\section{To cite this version:}

Sónia Ramos, Ingrid Chafsey, Michel Hébraud, Margarida Sousa, Patrícia Poeta, et al.. Ciprofloxacin stress proteome of the extended-spectrum beta-lactamase producing Escherichia coli from slaughtered pigs. Current Proteomics, 2016, 13, pp.285-289. 10.2174/1570164613666161018144215 . hal01602438

\section{HAL Id: hal-01602438 \\ https://hal.science/hal-01602438}

Submitted on 27 May 2020

HAL is a multi-disciplinary open access archive for the deposit and dissemination of scientific research documents, whether they are published or not. The documents may come from teaching and research institutions in France or abroad, or from public or private research centers.
L'archive ouverte pluridisciplinaire HAL, est destinée au dépôt et à la diffusion de documents scientifiques de niveau recherche, publiés ou non, émanant des établissements d'enseignement et de recherche français ou étrangers, des laboratoires publics ou privés. 
RESEARCH ARTICLE

\title{
Ciprofloxacin Stress Proteome of the Extended-Spectrum $\beta$-lactamase Producing Escherichia coli from Slaughtered Pigs
}

\author{
Sónia Ramos ${ }^{1,2,3,4}$, Ingrid Chafsey ${ }^{5}$, Michel Hébraud
Gilberto Igrejas
1,2,7, Margarida Sousa $^{1,2,3,4}$, Patrícia Poeta
4,7 and
}

${ }^{1}$ Functional Genomics and Proteomics Unit, University of Trás-os-Montes and Alto Douro, Vila Real, Portugal; ${ }^{2}$ Department of Genetics and Biotechnology, University of Trás-os-Montes and Alto Douro, Vila Real, Portugal; ${ }^{3}$ Centre for Animal and Veterinary Science, University of Trás-os-Montes and Alto Douro, Vila Real, Portugal; ${ }^{4}$ Department of Veterinary Science, University of Trás-os-Montes and Alto Douro, Vila Real, Portugal; ${ }^{5}$ UR454 Microbiology, Institut National de la Recherche Agronomique (INRA), Centre Auvergne-Rhône-Alpes, site de Theix, Saint-Genès Champanelle, France; ${ }^{6}$ Plate-Forme d'Exploration du Métabolisme composante protéomique, UR370 QuaPA, Institut National de la Recherche Agronomique (INRA), Centre Auvergne-Rhône-Alpes, site de Theix, Saint-Genès Champanelle, France; ${ }^{7}$ UCIBIO-REQUIMTE, Faculty of Technology and Science, University Nova de Lisboa, Caparica, Portugal

\begin{tabular}{l} 
A R T I C L E H I S T O R Y \\
\hline Received: March 24, 2016 \\
Revised: August 24, 2016 \\
Accepted: October 06, 2016 \\
DOI: \\
10.2174/1570164613666161018144 \\
215
\end{tabular}

\begin{abstract}
The increasing prevalence of bacteria resistant to even the most current arsenal of antibiotics is a serious concern for public health globally. The resistant bacteria which cause human infection are thought to emerge in food and animals. Our goal was to study the proteome of an extendedspectrum $\beta$-lactamase (ESBL)-producing Escherichia coli, SU03, strain recovered from faecal samples of pigs slaughtered for human consumption. This strain exhibited ciprofloxacin resistance associated with mutations in type II topoisomerase structural gene GyrA (Ser83Leu + Asp87Asn) and ParC (Ser80Ile). We studied how the proteome of this strain responded to stress by applying double the minimum inhibitory concentration of ciprofloxacin. The hydrolase L-asparaginase was overexpressed when SU03 was cultured with double the minimum inhibitory concentration of ciprofloxacin. Further research should determine how this enzyme contributes to ciprofloxacin resistance.
\end{abstract}

Keywords: Proteomics; Ciprofloxacin; ESBL; Escherichia coli; Antibiotic resistance.

\section{INTRODUCTION}

Escherichia coli with its wide range of pathologies is a major cause of human morbidity and mortality around the world [1]. E. coli is typically considered a benign commensal, but a variety of strains are pathotypes of partly zoonotic intestinal pathogenic $E$. coli or extraintestinal pathogenic $E$. coli (ExPEC) [2-3]. These pathogenic strains have the potential to cause a wide spectrum of intestinal and extra-intestinal diseases, such as urinary tract infections, septicaemia, meningitis, and pneumonia in both humans and animals [1-2]. Based on specific virulence factors and phenotypic traits, different pathotypes of enteric E. coli strains causing diarrhoea have been identified: enteropathogenic E. coli (EPEC), enterotoxigenic $E$. coli (ETEC), enteroinvasive $E$. coli (EIEC), enteroaggregative E. coli (EAggEC), diffusely adherent E. coli (DAEC), Vero cytotoxin producing E. coli (VTEC) or Shiga toxin-producing E. coli (STEC) [2, 4]. Outbreaks originating in contaminated food have been associated with VTEC, and to a lesser extent EPEC, ETEC and EaggEC strains [4].

*Address correspondence to this author at the Functional Genomics and Proteomics Unit, Department of Genetics and Biotechnology, University of Trás-os-Montes and Alto Douro, 5000-801 Vila Real, Portugal; Tel/Fax: +00 351259350 500,++00 351259350 480; E-mail: gigrejas@utad.pt
The use of antimicrobials in veterinary medicine as growth promoters has encouraged the proliferation of antibiotic-resistant $E$. coli in the endogenous microflora of animals [5]. Some resistant bacteria, which have emerged in food and animals, can cause human infection directly, whereas others can pass their resistance determinants by horizontal transmission to other bacteria pathogenic to humans [6]. The human body can become colonized and/or infected by resistant $E$. coli via direct contact, occupational exposure or via the food chain. Based on clear scientific evidence, the European Union completely banned the use of antibiotics as growth promoters in food animal production as of $1^{\text {st }}$ January, 2006 [7]. The increasing prevalence of bacteria resistant to the most up-to-date arsenal of antibiotics is a serious concern for global public health, given the increased health care costs and mortality rates [8].

Another related issue is how distinct antimicrobial classes are given in veterinary and human medicine, which can impair the efficiency of therapies due to co- and crossselection. These phenomena impelled the World Health Organization (WHO) to classify certain antibiotics, such as fluoroquinolones, third- and fourth-generation cephalosporins, and macrolides, as being critically important for human medicine [9]. For instance, quinolones are broad- 
spectrum antibacterial agents, commonly used in both clinical and veterinary medicines. Enrofloxacin was the first of the fluoroquinolones approved for use in animals in the late 1980s [10]. Although ciprofloxacin is not approved for use in animal therapy, it is the main metabolite of enrofloxacin currently used for the treatment of gastrointestinal and respiratory infections in several animal species, including pigs suffering with diseases caused by Gram-positive and Gramnegative bacteria [11]. The extensive use and misuse of fluoroquinolones has resulted in the rapid development of bacterial resistance to these agents and in human therapy ciprofloxacin is known as the most widely used antibacterial agent in the world [12].

The emerging resistance to fluoroquinolones and the production of extended-spectrum $\beta$-lactamases (ESBL) by Multidrug Resistance (MDR) E. coli strains have raised further concern over the last decade due to the limited therapeutic options available $[3,5]$. ESBL-producing strains have shown to be significantly more frequent among ciprofloxacin-resistant $E$. coli than among susceptible strains [13]. It is noteworthy that fluoroquinolone resistance in E. coli is not restricted to clinical isolates, but is commonly present in the healthy population and animals [5]. In fact, we have previously shown that more than $90 \%$ of ESBL-producing E. coli isolates detected in pigs are MDR, with some of them being resistant to ciprofloxacin [14].

Proteomics can been used to study bacterial physiology, and to fill in the multiple gaps which remain in our understanding of resistance and how it is transmitted between hosts in different ecosystems. Several studies have shown that in different bacteria some proteins are differentially expressed in response to antibiotic stress [15-18]. Proteomic detection of specific proteins expressed in response to antibiotic stress has proved to be a remarkable tool in developing vaccines against MDR pathogens [19]. Proteomics research thus offers major opportunities to characterize bacterial pathogens, elucidate disease mechanisms and identify new diagnostic markers and therapeutic targets [16].

Our goal was to study the proteomes of an ESBLproducing E. coli strains, SU03), recovered from faecal samples of pigs slaughtered for human consumption [14]. A proteomic survey, by means of two-dimensional electrophoresis (2-DE) and statistical analysis employing Progenesis SameSpot, was performed to identify differentially expressed proteins in one MDR ESBL-producing $E$. coli strain subject to ciprofloxacin stress. The main objective was to establish the range of proteins present in this bacterium, focusing on those previously associated with antibiotic resistance and stress responses.

\section{MATERIALS AND METHOD}

\subsection{Bacterial Strains and Culture Conditions}

We chose to study strain SU03, an ESBL-producing $E$. coli, previously characterized and recovered from faecal samples of pigs slaughtered for human consumption [14]. A preculture was set up from 2 or 3 individual colonies and grown in brain heart infusion broth, at $37^{\circ} \mathrm{C}$ with shaking at $150 \mathrm{rpm}$, overnight. Then $300-\mathrm{mL}$ cultures were started from the precultured cells (at an initial OD600nm $\sim 0.01$ ), and when they reached an OD600nm of 0.1 were split into two $150 \mathrm{ml}$ cultures; to one of them, $8 \mu \mathrm{g} / \mathrm{ml}$ of ciprofloxacin was added, the double of its minimum inhibitory concentration. The culture without an antibiotic was incubated at $37^{\circ} \mathrm{C}$ until the end of the log growth phase (OD600nm $\sim 1.3,4$ to $5 \mathrm{~h}$ later). Three biological replicates were performed for each condition.

\subsection{Protein Extraction and Quantitation}

Cells were collected by centrifugation (15 min, $7500 \mathrm{~g}$ ) and cell pellets were washed twice with TE buffer. Cells were re-suspended and disrupted with a Constant Cell Disruption System at $2.5 \mathrm{kbar}$. Lysed cells were treated with DNase I and RNase A (1\% vol/vol) and cell debris were separated by centrifugation $\left(13000 \mathrm{~g}, 20 \mathrm{~min}, 4^{\circ} \mathrm{C}\right)$. The precipitate was washed with ice-cold acetone and solubilized in an isoelectric focusing (IEF) buffer. Proteins were quantified by the Bradford method using bovine serum albumin as the standard [20].

\subsection{Two-dimensional Gel Electrophoresis (2-DE) and Statistical Analysis}

Precast IPG $18 \mathrm{~cm}$ strips with a $\mathrm{pH} 4-7$ linear gradient were loaded with $500 \mu \mathrm{g}$ of the protein sample. Gel electrophoresis and gel staining were performed as previously described [17]. Gels were stained with Colloidal Coomassie Blue G250. Stained gels were scanned using GS-800 imaging densitometer (Bio-Rad) and images were analysed using Image Master 2D Platinum 5.0 (Amersham Biosciences, Saclay, France). Statistical image analysis was performed using Progenesis Samespots software, version 4.1 (Nonlinear Dynamics). Differential spot intensity was considered significant at $p \leq 0.01$ using analysis of variance (ANOVA) and these spots were manually excised from the gels and processed for mass spectrometry (MS).

\subsection{Protein Identification}

The protein spots extracted from the gels were destained as previously described [21]. After tryptic digestion, peptide fragments were analysed using a MALDI-TOF/TOF MS (AutoFlex Speed, Bruker Daltonics) or a LC-ESI-IT-MS/MS (LTQ Velos, ThermoScientific). The output files were analysed by MASCOT (internal licence, V.2.3) either via the ProteinScape query server (version 3.0.0 346) for the PMF data or via Proteome Discoverer (version 1.3) for the MS/MS data. The database used was EBI Bacteria. The main parameters considered were: possible alkylation of cysteines $(\mathrm{C})$ by iodoacetamide and oxidation of methionines (M), a mass tolerance of $25 \mathrm{ppm}$ for PMFs, $200 \mathrm{ppm}$ for parent ions (MS) and 0.3 Da for fragment ions (MS/MS) for the MALDI-TOF/TOF MS/MS analyses, 1.5 Da for parent ion (MS) and $0.8 \mathrm{Da}$ for fragment ions (MS/MS) for the LCESI-IT analyses. For PMF identification, a protein was validated with at least 4 peptides, a coverage rate of about $20 \%$ and a score of $-10 \times \log (\mathrm{P})$ where $\mathrm{P}$ is the probability that the observed match is a random event. For MS/MS analyses from MALDI-TOF/TOF, an individual ion score $>52$ indicates identity or extensive homology $(\mathrm{p}<0.05)$. For MS/MS analyses from LC-ESI-IT, the identification of a protein was validated by at least two peptides and a false positive rate 


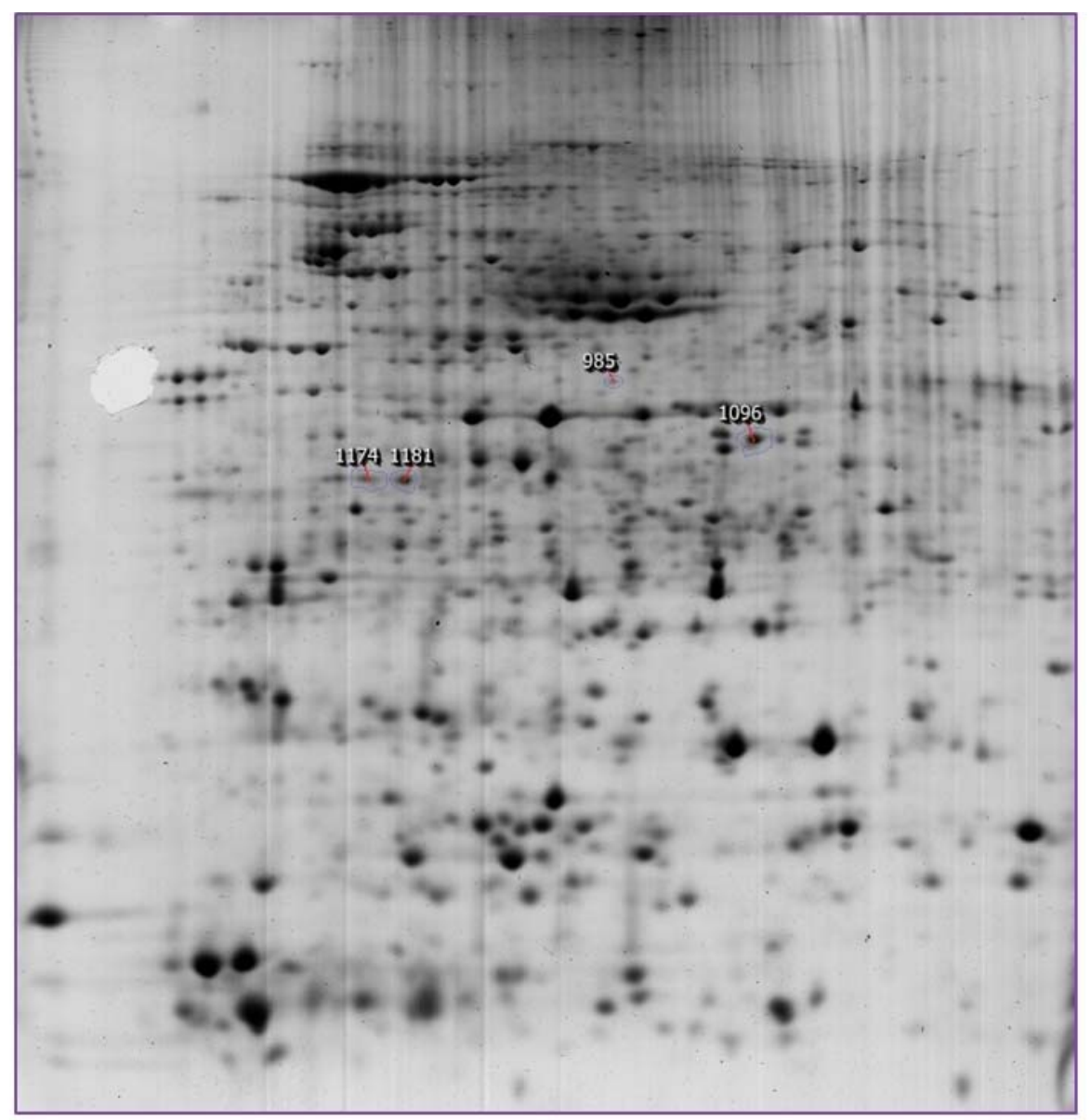

Fig. (1). Representative 2-DE protein profile of the total cellular proteins obtained from ESBL multi-resistant E. coli strains SU03. This image corresponds to the reference gel used for comparison. The spots identified were excised from the gel, trypsinolyzed, and subjected to MALDI-TOF/TOF identification.

less than $5 \%$. When positive identification was not possible by MALDI-TOF/TOF, proteins were identified by nanoliquid chromatography (LC, Ultimate 3000, Dionex) coupled to electrospray ionization (ESI) and tandem mass spectrometry (MS/MS).

\section{RESULTS}

To gain insight into the physiological changes conferring resistance to ciprofloxacin, we compared the proteomes of a naturally occurring MDR ESBL-producing E. coli strain, SU03, grown with and without ciprofloxacin. In this strain, ciprofloxacin resistance was associated with mutations in type II topoisomerase structural gene GyrA (Ser83Leu + Asp87Asn) and ParC (Ser80Ile) [14]. We used IEF strips with a linear gradient of $\mathrm{pH}$ 4-7 for 2-DE of total cellular proteins from SU03, which yielded a better spread display of protein spots (Fig. 1). Statistical image analysis was used to detect which proteins were differentially expressed.

The abundance of three spots was changed in cultures supplemented with ciprofloxacin. In these spots the variation of protein expression was considered statistically significant with $\mathrm{p} \leq 0.01$ and all of the three identified proteins were highly expressed under ciprofloxacin stress (Table 1). Two of the protein spots were identified as putative uncharacter- ized proteins (spots 1181 and 1174) and the protein Lasparaginase II was identified in spot 1096.

\section{DISCUSSION}

The elucidation of drug resistance mechanisms is a very active research area that bridges several disciplinary boundaries, and proteomic methodologies are extremely useful in studying the physiological response of bacterial cells to various environmental stresses, including stress caused by antibiotic action. Under ciprofloxacin stress conditions we found out that the enzyme L-asparaginase was overexpressed by this ESBL-producing E. coli strain.

L-asparaginase II from E. coli is well-known as it has been clinically used for the past 30 years to treat acute lymphoblastic leukaemia and lymphosarcoma. L-asparaginase is an antineoplastic agent which selectively decreases the level of L-asparagine in blood and diminishes the proliferation of cancerous cells which do not synthesize this amino acid [22]. In addition, the E.coli L-asparaginase is associated with significant glutaminase activity which has the deleterious effect of reducing protein synthesis [22]. Indeed L-asparaginase therapy reduces the level of several important proteins [22]. It is conceivable that up-regulated L-asparaginase could influence the production of other proteins in strain SU03 under 
Table 1. Proteins differentially expressed and identified by MALDI-TOF/TOF or LC-ESI MS/MS in the MDR ESBL-producing E. coli, strains SU03, under ciprofloxacin stress.

\begin{tabular}{|c|c|c|c|c|c|c|c|c|c|c|c|}
\hline \multirow{2}{*}{ Spots } & \multicolumn{2}{|c|}{ Spots Image ${ }^{\text {a }}$} & \multirow{2}{*}{$\begin{array}{l}\text { Protein } \\
\text { Description }\end{array}$} & \multirow{2}{*}{$\begin{array}{l}\text { Gene } \\
\text { Name }\end{array}$} & \multirow{2}{*}{$\begin{array}{l}\text { Accession } \\
\text { Number }^{b}\end{array}$} & \multirow{2}{*}{ Species } & \multirow{2}{*}{$\begin{array}{l}M W \\
{[\mathrm{kDa}]}\end{array}$} & \multirow{2}{*}{$\begin{array}{l}\text { Protein } \\
\text { pI }\end{array}$} & \multirow{2}{*}{$\begin{array}{l}\text { Peptide } \\
\text { Matches }^{d}\end{array}$} & \multirow{2}{*}{$\begin{array}{l}\text { Protein } \\
\text { Score }^{\mathrm{d}}\end{array}$} & \multirow{2}{*}{$\begin{array}{l}\text { Seq. } \\
\text { coverage }^{d}\end{array}$} \\
\hline & $\begin{array}{c}\text { Without } \\
\text { CIP }^{\text {b }}\end{array}$ & With CIP $^{\text {b }}$ & & & & & & & & & \\
\hline 1096 & & & $\begin{array}{l}\mathrm{L}- \\
\text { asparaginase } \\
2\end{array}$ & ans $\mathrm{B}$ & $\begin{array}{l}\text { COKWF5 } \\
\text { ECOLX }\end{array}$ & $\begin{array}{l}\text { E. coli } \text { LF82 is an } \\
\text { adherent-invasive } E \text {. } \\
\text { coli (AIEC) strain } \\
\text { isolated from a } \\
\text { patient with Crohn's } \\
\text { disease. }\end{array}$ & 36.80 & 5.67 & 6 & $88(338)$ & $20 \%$ \\
\hline 1181 & 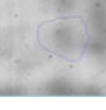 & 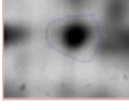 & $\begin{array}{l}\text { uncharacter- } \\
\text { ized protein }\end{array}$ & & W1BTH3 & $\begin{array}{l}\text { Escherichia coli } \\
\text { IS25 }\end{array}$ & 30.44 & 4.97 & 4 & 55 (229) & $25.60 \%$ \\
\hline 1174 & & & $\begin{array}{l}\text { Putative } \\
\text { uncharacter- } \\
\text { ized protein }\end{array}$ & $y f d \mathrm{Q}$ & $\begin{array}{l}\text { F0JNJ3_ES } \\
\text { CFE_ESCF } \\
\text { E }\end{array}$ & $\begin{array}{l}\text { Escherichia } \\
\text { fergusonii ECD227 }\end{array}$ & 30.40 & 4.97 & 1 & 82 & $4.70 \%$ \\
\hline
\end{tabular}

${ }^{\mathrm{a}}$ The listed proteins displayed a statistical difference of spot volume ratio between all the strains, with and without an antibiotic, with an ANOVA $\mathrm{p}<0.01$.

${ }^{\mathrm{b}}$ CIP- Ciprofloxacin

${ }^{\mathrm{c}}$ The database used was EBI_Bacteria for MALDI-TOF/TOF and Local Mix_Mouse_Ecoli database for LC-ESI MS/MS

${ }^{\mathrm{d}}$ For spots 1096 and 1181 identification by MALDI-TOF/TOF, PMF was first considered for protein validation with at least 4 peptides, a coverage rate of about $20 \%$ and a score of $10 \times \log (\mathrm{P})$ where $\mathrm{P}$ is the probability that the observed match is a random event. Peptides were then analysed by MS/MS and the score is given in brackets. Spot 985 was identified by LC-ESI MS/MS because of a low score in PMF.

ciprofloxacin stress. Moreover, quinolone resistance in Gram-negative bacteria can be mediated by the hyperexpression of some efflux pumps [23]. L-asparaginase may be one of these pumps as it is a hydrolase which could be diverted from primary metabolism to the stress response. In conclusion, this enzyme should be further researched to determine its role in ciprofloxacin resistance. Nevertheless an effect on expression of L-asparaginase is very likely a consequence of ciprofloxacin toxicity not directly related to resistance, which is well understood to involve changes in target topoisomerase II enzymes, porins, pumps, and plasmidmediated mechanisms $[24,25]$.

Additionally, two proteins annotated as putative uncharacterized proteins with unknown functions were identified. Proteomic and genetic studies focusing on the presence of these proteins during growth phase, stress, or other processes may give insight into their functions and roles. Overall, the results of the ciprofloxacin experiment were surprising as they differed from previous investigations of the primary response to fluoroquinolones. Previously, it was shown that fluoroquinolone exposure caused substantial changes in the transcriptional profile of $E$. coli, particularly of repressed genes, including those involved in metabolism, transport of small molecules, protein synthesis and encoding OMPs [26, 27], and these effects were dependent upon both the concentration and period of exposure to fluoroquinolone. More recently, 42 differentially expressed proteins were identified in $E$. coli exposed to enrofloxacin, including proteins involved in classic resistance mechanism, such as bacterial cell membrane permeability mediated by OmpX and OmpW [28]. Our different results could be explained by species-specific effects, or be related to differences in the design or execution of the experiments, such as ciprofloxacin concentration used or the time of exposure.

\section{CONCLUSION}

As little is known about the structural and metabolic changes in the cell which triggers resistance to antimicrobial agents, proteomic analysis and protein identification are reliable complementary tools to improve our knowledge in this field.

In this proteomic analysis, we have found that when the ESBL-producing E. coli strain was treated with ciprofloxacin, the enzyme L-asparaginase was overexpressed. The abundance of this hydrolase may lead to a diverse secondary response by influencing the production of other proteins or directly mediating ciprofloxacin resistance.

Comparative assessment and integration of genome and proteome-wide techniques will improve our knowledge about bacterial growth, virulence and interaction with its environment, especially under antibiotic stress. It will particularly help in narrowing down the number of potential targets of interest by rapidly identifying gene products which are really required for bacterial survival and discounting non-translated genes, thus reducing risk and inefficiency in developing new drugs.

\section{CONFLICT OF INTEREST}

The author(s) confirm that this article content has no conflict of interest.

\section{ACKNOWLEDGEMENTS}

We acknowledge that this work is in part derived from a $\mathrm{PhD}$ thesis by Sónia Ramos which was unpublished previously in a journal article format and hereby confirm that all data presented here are original and being reported for the first time. 
We gratefully acknowledge the financial support derived from national funds of the Fundação para a Ciência e Tecnologia (FCT), cofinanced by POPH QREN Type 4.1Advanced Training and subsidized by the European Social Fund and National Funds of the Ministry of Science and Technology for High Education (MCTES) to Sónia Ramos, and Margarida Sousa (SFRH/BD/47706/2008, SFRH/BD/ $87302 / 2012$, respectively). The authors are grateful to the Research Unit on Applied Molecular Biosciences (UCIBIO) which is financed by national funds from FCT/MEC (UID/Multi/04378/2013) and cofinanced by the ERDF under the PT2020 Partnership Agreement (POCI-01-0145-FEDER007728).

\section{REFERENCES}

[1] Touchon, M.; Hoede, C.; Tenaillon, O.; Barbe, V.; Baeriswyl, S.; Bidet, P.; Bingen, E.; Bonacorsi, S.; Bouchier, C.; Bouvet, O.; Calteau, A.; Chiapello, H.; Clermont, O.; Cruveiller, S.; Danchin, A.; Diard, M.; Dossat, C.; Karoui, M.E.; Frapy, E.; Garry, L.; Ghigo, J.M.; Gilles, A.M.; Johnson, J.; Le Bouguenec, C.; Lescat, M.; Mangenot, S.; Martinez-Jehanne, V.; Matic, I.; Nassif, X.; Oztas, S.; Petit, M.A.; Pichon, C.; Rouy, Z.; Ruf, C.S.; Schneider, D.; Tourret, J.; Vacherie, B.; Vallenet, D.; Medigue, C.; Rocha, E. P.; Denamur, E. Organised genome dynamics in the Escherichia coli species results in highly diverse adaptive paths. PLoS genetics 2009, 5 (1), e1000344.

[2] Allocati, N.; Masulli, M.; Alexeyev, M.F.; Di Ilio, C. Escherichia coli in Europe: an overview. Int. jour.of env. res.and pub. hea. 2013, 10 (12), 6235-54.

[3] Ewers, C.; Bethe, A.; Semmler, T.; Guenther, S.; Wieler, L.H. Extended-spectrum beta-lactamase-producing and AmpCproducing Escherichia coli from livestock and companion animals, and their putative impact on public health: A global perspective. Clinical microbiology and infection : the official publication of the European Society of Clinical Microbiology and Infectious Diseases 2012, 18 (7), 646-55.

[4] Newell, D.G.; Koopmans, M.; Verhoef, L.; Duizer, E.; AidaraKane, A.; Sprong, H.; Opsteegh, M.; Langelaar, M.; Threfall, J.; Scheutz, F.; van der Giessen, J.; Kruse, H. Food-borne diseases the challenges of 20 years ago still persist while new ones continue to emerge. Int. jour. of food mic. 2010, 139 Suppl 1, S3-15.

[5] Von B.H.; Marre, R. Antimicrobial resistance of Escherichia coli and therapeutic implications. Int. jour. of med. mic.: IJMM 2005, 295 (6-7), 503-11.

[6] Aidara-Kane, A. Containment of antimicrobial resistance due to use of antimicrobial agents in animals intended for food: WHO perspective. Revue scientifique et technique 2012, 31 (1), 277-87.

[7] "REGULATION (EC) No 1831/2003 OF THE EUROPEAN PARLIAMENT AND OF THE COUNCIL", Official Journal of the European Union (EN), L 268/29.

[8] Polyak, S.W.; Abell, A.D.; Wilce, M.C.; Zhang, L.; Booker, G.W. Structure, function and selective inhibition of bacterial acetyl-coa carboxylase. Applied microbiology and biotechnology 2012, 93 (3), 983-92.

[9] World Health Organization (WHO) (2011). - WHO list of critically important antimicrobials, n. R. A. a. h. a. w. i. i. b.

[10] Martinez, M.; McDermott, P.; Walker, R. Pharmacology of the fluoroquinolones: a perspective for the use in domestic animals. Veterinary journal 2006, 172 (1), 10-28.

[11] Araneda, C.; Villar, P.; Cuadros, C.; Valle, M.; Nunes, P.; Santelices, M. Single and Multiple Pharmacokinetics of Enrofloxacin and Ciprofloxacin in Pigs. J Bioequiv Availab 2013, 5 (1), 041-046.
[12] Al-Agamy, M.A.; Zaki, S. A. Mechanisms of fluoroquinolones resistance in Escherichia coli isolates from Saudi Arabia. African Journal of Microbiology Research 2012, 6 (1), 155-159.

[13] Drago, L.; Nicola, L.; Mattina, R.; De Vecchi, E., In vitro selection of resistance in Escherichia coli and Klebsiella spp. at in vivo fluoroquinolone concentrations. BMC microbiology 2010, 10, 119.

[14] Ramos, S.; Silva, N.; Dias, D.; Sousa, M.; Capelo-Martinez, J.L.; Brito, F.; Canica, M.; Igrejas, G.; Poeta, P. Clonal diversity of ESBL-producing Escherichia coli in pigs at slaughter level in Portugal. Foodborne pathogens and disease 2013, 10 (1), 74-9.

[15] Dos Santos, K.V.; Diniz, C.G.; Veloso L.C.; De Andrade, H.M.; Giusta M.S.; Pires S.F.; Santos, A.V.; Apolonio, A.C.; De Carvalho, M.A.; Farias L.M. Proteomic analysis of Escherichia coli with experimentally induced resistance to piperacillin/tazobactam. Research in microbiology 2010, 161 (4), 268-75.

[16] Radhouani, H.; Nunes-Miranda, J.D.; Carreira, R.J.; Santos, H.M.; Pinto, L.; Monteiro, R.; Carvalho, C.; Poeta, P.; Lodeiro, C.; Capelo-Martinez, J.L.; Igrejas, G. Proteomic changes in an extended-spectrum beta-lactamase-producing Escherichia coli strain under cefotaxime selection. Journal of Integrated Omics 2013, 3 (2), 157-166.

[17] Coldham, N.G.; Randall, L.P.; Piddock, L.J.; Woodward, M.J. Effect of fluoroquinolone exposure on the proteome of Salmonella enterica serovar Typhimurium. The Journal of antimicrobial chemotherapy 2006, 58 (6), 1145-53.

[18] Poutanen, M.; Varhimo, E.; Kalkkinen, N.; Sukura, A.; Varmanen, P.; Savijoki, K. Two-dimensional difference gel electrophoresis analysis of Streptococcus uberis in response to mutagenesisinducing ciprofloxacin challenge. Journal of proteome research 2009, 8 (1), 246-55.

[19] Lima, T.B.; Pinto, M.F.; Ribeiro, S.M.; De Lima, L.A.; Viana, J.C.; Gomes J.N.; Candido E.S.; Dias, S.C.; Franco, O.L. Bacterial resistance mechanism: What proteomics can elucidate. FASEB journal : official publication of the Federation of American Societies for Experimental Biology 2013, 27 (4), 1291-303.

[20] Bradford, M.M. A rapid and sensitive method for the quantitation of microgram quantities of protein utilizing the principle of proteindye binding. Analytical biochemistry 1976, 72, 248-54.

[21] Renier, S.; Chambon, C.; Viala, D.; Chagnot, C.; Hebraud, M. Desvaux, M. Exoproteomic analysis of the SecA2-dependent secretion in Listeria monocytogenes EGD-e. Journal of proteomics 2013, 80C, 183-195.

[22] Nagarethinam, S.; Nagappa, A.N.; Udupa N.U.; Rao, V.J.; Vanathi, M.B. Microbial L-Asparaginase and its future prospects. Asian J Med Res 2012, 1 (4), 160-168.

[23] Cambau, E.; Guillard, T. Antimicrobials that affect the synthesis and conformation of nucleic acids. Revue scientifique et technique 2012, 31 (1), 77-87, 65-76.

[24] Sanzey, B. Modulation of gene expression by drugs affecting deoxyribonucleic acid gyrase. Journal of Bacteriology 1979, 138, 40-47.

[25] Smith, C.L.; Kubo, M.; Imamoto, F. Promoter-specific inhibition of transcription by antibiotics which act on DNA gyrase. Nature 1978, 275, 420-423.

[26] Kaldalu, N.; Mei, R.; Lewis, K. Killing by ampicillin and ofloxacin induces overlapping changes in Escherichia coli transcription profile. Antimicrobial agents and chemotherapy 2004, 48 (3), 8906.

[27] Shaw, K.J.; Miller, N.; Liu, X.; Lerner, D.; Wan, J.; Bittner, A.; Morrow, B.J. Comparison of the changes in global gene expression of Escherichia coli induced by four bactericidal agents. Journal of molecular microbiology and biotechnology 2003, 5 (2), 105-22.

[28] Qi, J.; Du, Y.; Bai, H.; Zhu, X.; Hu, M.; Luo, Y.; Liu, Y. Global protein expression profile response of Escherichia coli ATCC 25922 exposed to enrofloxacin. Microbial drug resistance 2013, 19 (1), 6-14.

DISCLAIMER: The above article has been published in Epub (ahead of print) on the basis of the materials provided by the author. The Editorial Department reserves the right to make minor modifications for further improvement of the manuscript. 